\title{
Organizational aspects of landscape enterprises: The case of Istanbul
}

\section{Nur Aytül Temiz ${ }^{1}$ (C) Seçil Yurdakul Erol ${ }^{2 *}$ (]}

${ }^{1}$ Aytül Temiz Bahçe Mimari ve Mühendislik Hizmetleri, Istanbul, Turkey.

${ }^{2}$ Department of Forest Policy and Administration, Faculty of Forestry, Istanbul University-Cerrahpasa, Orman Fakultesi Valide Sultan Caddesi, Bahcekoy, Sarıyer, Istanbul, Turkey. E-mail: secily@iuc.edu.tr. "Corresponding author.

\begin{abstract}
As a management function, organizing deals with activities designed to support the realization of institutional goals and plans, performed within an organizational structure that serves to connect, direct, manage, and control the activities associated with these plans and goals. Considering the extensive scope of landscape architecture, it is necessary for organizations operating in this field to focus on management and organization issues (which have ecological, architectural, economic, and social dimensions), and their integration with administrative functions to achieve success. In this context, the present study examined the organizing processes of private enterprises operating in the landscape sector, investigated the differences among them, and analyzed the interaction of organization-related aspects. Within this scope, the research focused on evaluating stages of organizing, principles and effects of organizing, organizational relations, and organizational authorities and responsibilities. The province of Istanbul was selected as a case study to consider the specified objectives. Data were collected through questionnaires and then sent through ANOVA and Spearman correlation analyses. The results showed that the main problems affecting these enterprises in terms of organizing were delegation, participative management, and inter-departmental relations. Organizational aims and customer groups were also shown to have an impact on these issues, and the components of the organizing function distinct relationships with one another. This study concluded that adopting a holistic approach in organizational processes and related applications is essential. Key words: organization, organizing function, landscape enterprises.
\end{abstract}

Aspectos organizacionais das empresas de arquitetura paisagista: o caso de Istambul

RESUMO: Enquanto função de gestão, a organização ocupa-se das atividades que apoiam a realização dos objetivos e planos institucionais e da estrutura organizacional; é, por isso, um instrumento essencial de ligação entre os planos, que dirige, conduz e controla atividades. Tendo em conta a abrangência da área da arquitetura paisagista, é necessário que as empresas que atuam neste setor se foquem em questões relacionadas com gestão e organização para serem bem-sucedidas. Estas organizações têm de ter em conta aspetos ecológicos, arquitetónicos, económicos e sociais integrados em aspetos administrativos. Neste contexto, o objetivo deste estudo é examinar as estruturas organizacionais e o processo de organização em empresas privadas que atuam no setor da arquitetura paisagista, analisando as diferenças entre elas. A interação entre os aspetos relacionados com organização foi também analisada. Neste âmbito, este estudo procurou avaliar as etapas de organização, os princípios e efeitos da organização, as relações organizacionais, e também a autoridade e a responsabilidade. A provincia de Istambul foi a escolhida para constituir a amostra e alcançar os objetivos propostos. Os dados foram recolhidos através de questionários submetidos a empresas de arquitetura paisagista que atuam na província, tendo sido depois analisados com recurso à ANOVA è à análise da correlação de Spearman. Descobriu-se que os principais problemas destas empresas em termos de organização são a delegação, a gestão participativa e as relações interdepartamentais. Descobriu-se ainda que a sua missão e os grupos de clientes afetam os aspetos relacionados com organização, e que as componentes da função de organização estão relacionadas entre si. A importância de uma abordagem integral aos processos organizacionais e às aplicações relacionadas com os mesmos é fundamental.

Palavras-chave: organização, função de organização, empresas de arquitetura paisagista.

\section{INTRODUCTION}

Management is the main organ for decision making, organizing, directing, leading, and realizing objectives in business. The primary role is to coordinate work and lead staff to improve efficiency and achieve their goals (DRUCKER, 2007). There are four essential functions of management, namely: planning, organizing, leading, and controlling. As a management function, organizing focuses on the activities designed to support institutional goals and plans. In this sense, the organizing function is related to the determination and grouping of tasks, management of interaction between various jobs, assignment of job duties, and design of the organizational units (SCHRAEDER et al., 2014). The organizing function 
also deals with the organizational structure design, the relationships between individuals, and administrative resource allocation (DYCK \& NEUBERT, 2009).

Organizing is recognized as a typical/ classic managerial function and has remained one of management's organic functions. In today's notion of organizing, the organization is viewed as a living system. It focuses heavily on reality and change, recognizing and adapting to environmental conditions and crises, shaping organizational bureaucracy, customer-related issues, and supporting organizational communication (MCNAMARA, 2009). The design of the organizing process is governed by several fundamental principles, including chain of command, responsibility, unity of command, accountability, delegation, departmentalization, specialization, and coordination (HALUSHACK \& HALUSHCHAK, 2015). The other principles of this process include customer-oriented focus, empowered and autonomous units, clear directions, resource management, social and technical integration, accessible information flow, job enrichment and teamwork, strong people management practices, performance support, and capacity to reconfigure (STANFORD, 2005).

As a managerial function, organizing has impacts on organizational land human resources performance (SARBOLAND, 2012; KABIRU et al., 2018). Generally, the organizing function and the organizational structure have a direct relationship with planning, the leading and controlling functions of management, and many aspects of human resources applications and organizational behavior.

Organizational relationships are one of the core aspects of organizing functions. According to this approach, the organization is a system that involves interaction between jobs, units, operating processes, people, and groups (AHMADY et al., 2016). The organizational structure serves as the platform for inter-organizational communication and is designed for communication purposes (TRAN \& TIAN, 2013). The different types of organization designs affect the informal relationships and the communication within an organization in various ways (DIEFENBACH \& SILLIENCE, 2011). Delegating authority and responsibility, giving independence to staff in terms of decision making and implementations, decentralization, participation, collaboration, coordination, supervision, and empowerment are all factors that have direct relationships with the essential features of modern organizing (STANFORD, 2005; PICOT et al., 2008; MORSCHETT et al., 2009).

The business field of landscape architecture is often divided into urban and rural areas. Urban- related business fields of landscape architecture may concern ground-level gardens, roof and terrace gardens, mass housing gardens, playgrounds, district parks, school gardens, sports fields, green fields on roads and squares, green areas of public and private institutions, urban parks and forests, zoos, botanical gardens, historical and archaeological sites, places of worship, cemeteries, fairs, cultural parks, and garden exhibitions (FOSTER, 2010; GÜL, 2000). Rural-related landscape architecture is generally at the region and basin-scale and is often related to environmental planning and land-use. Related activities include those performed on agricultural areas, industrial areas, transportation areas, forest areas, and tourism areas (GÜL, 2000). Rural-related landscape architecture has also expanded recently to include mines, active rail corridors, marine ports, landfills, interstate overpasses, river spillways, and old factory sites (DAVIS \& OLES, 2014). Landscape architecture involves analyzing, planning, designing, managing, and developing both built and natural environments (ASLA, 2020). The discipline also concerns long-term ecological management of landscapes and nature-human relations, including the changing needs of people (ENTWISTLE \& KNIGHTON, 2013).

Considering the broad field of landscape architecture business, it is necessary for organizations operating in this discipline to focus on management and organizational issues to achieve success. These organizations have to deal on the administrative scale with ecological, architectural, economic, and social issues. In this context, this study examined the organizing processes of private enterprises operating in the landscape sector, investigate the differences among these enterprises, and analyze the relationship between the evaluated aspects' variables and their impact. In addition, this study identified problems and made suggestions for the related enterprises by assessing the stages of organizing, the principles and effects of organizing, organizational relations, and the relevant authorities and responsibilities.

\section{MATERIALS AND METHODS}

The research consists of two main stages: we first determined the cases of study, then collected and analyzed data (Figure 1). In the first stage, we researched enterprises registered with the Chamber of Landscape Architects throughout Turkey. Of the 341 registered enterprises in Turkey, 66 of them operate in Istanbul. Similarly, the city with the highest number of landscape enterprises in Turkey is Istanbul. Using 


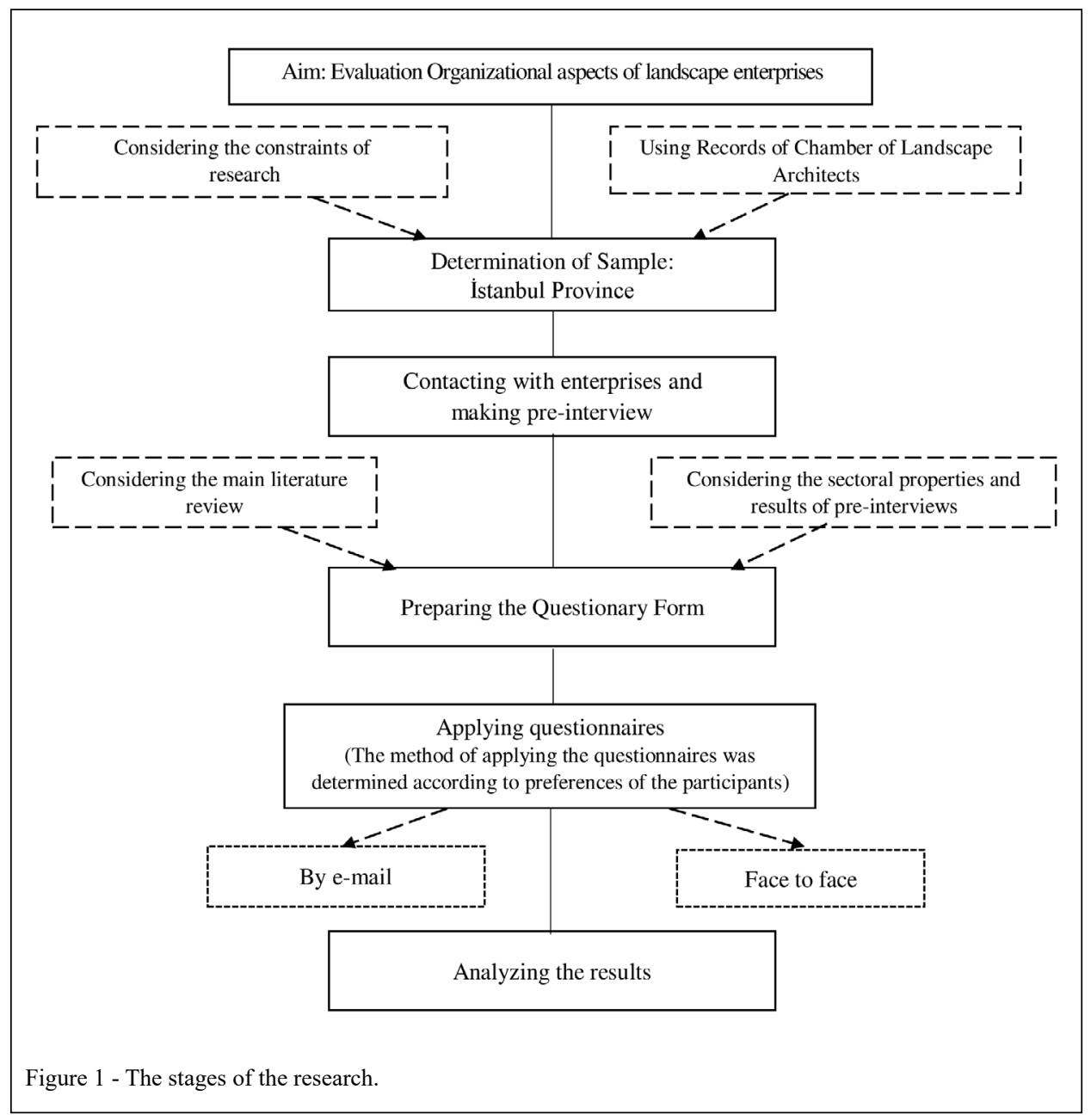

the purposive sampling method, we thus decided to carry out the study within the framework of landscape enterprises located in Istanbul. After selecting the cases, we contacted the Chamber of Landscape Architects and gathered the enterprises' contact information, to which we sent the questionnaires. Some questionnaires; however, were administered face to face. Regardless, all of the questionnaires were given to senior managers in the selected businesses. Total population sampling was made in the survey and the questionnaires were delivered to all 66 enterprises. However, representatives of some enterprises opted not to participate. The confidence level is $95 \%$ and the error margin is 0,05 ; according to the confidence level and error margin accepted, the sample size (n) are calculated as $n \geq 34$. In total, 35 senior managers agreed to participate in the study. The characteristics of these enterprises can be seen in table 1.

The questionnaire consisted of two sets of questions. The first set, consisting of openended questions, included questions about the field, operation time, customer groups, the company's main aims, and employee status. The second set comprised 54 questions about the stages, principles, and effects of organizing, organizational relations, and authority and responsibility at the enterprise. While designing this questionnaire, we examined and attributed relevant literature related to management, organization, and sectoral characteristics. The general framework of the questionnaire derives partly from the approach of ÖZDÖNMEZ et al. (1998), who evaluated the main aspects of organizing in the context of nature-related organizations including landscape architecture. This framework was further improved by a range of other 
Table 1 - Frequency and percentage of features related to the enterprises that responded to the questionnaire.

\begin{tabular}{|c|c|c|c|}
\hline Features of Enterprise & & $\mathrm{N}^{*}$ (Frequency) & $\%$ (Percentage $)$ \\
\hline \multirow{4}{*}{ Business Field (in Landscape Sector) } & Production & 9 & 9.8 \\
\hline & Design and Planning & 33 & 35.9 \\
\hline & Project Application & 31 & 33.7 \\
\hline & Supply Service & 19 & 20.7 \\
\hline \multirow{3}{*}{ Operation Period } & $1-5$ Years & 8 & 22.9 \\
\hline & 6-10 Years & 8 & 22.9 \\
\hline & More than 11 Years & 19 & 54.2 \\
\hline \multirow{2}{*}{ Business Field (outside of Landscape Sector) } & Have business outside of Lnd. Sec. & 12 & 34.3 \\
\hline & Do not have business outside of Lnd. Sec. & 23 & 65.7 \\
\hline \multirow{7}{*}{ Serviced Customer Group } & Municipalities & 19 & 12.9 \\
\hline & Public Institutions & 22 & 15.0 \\
\hline & Building Enterprises & 32 & 21.8 \\
\hline & Hotels and Holding Companies & 24 & 16.3 \\
\hline & Education Institutions & 16 & 10.9 \\
\hline & Home Owners & 31 & 21.1 \\
\hline & Other & 3 & 2.0 \\
\hline \multirow{5}{*}{ Main aims of Enterprise } & Generate Profit & 23 & 24.0 \\
\hline & Growth & 20 & 20.8 \\
\hline & Continuity & 30 & 31.3 \\
\hline & Social Service & 22 & 22.9 \\
\hline & Other & 1 & 1.0 \\
\hline \multirow{3}{*}{ Number of Employees } & Less than 10 & 20 & 57.1 \\
\hline & $10-20$ & 9 & 25.7 \\
\hline & More than 20 & 6 & 17.1 \\
\hline \multirow{3}{*}{ Number of Architects and Engineers } & $1-2$ & 17 & 48.6 \\
\hline & $3-5$ & 8 & 22.9 \\
\hline & More than 5 & 10 & 28.6 \\
\hline
\end{tabular}

*Since there are multiple responses in some sections, the total number (N) exceeds the number of samples.

theoretical studies (DIVE, 2004; BALIG, 2006; HERNES, 2008; PICOT et al., 2008; SOYKA, 2012).

The expressions evaluated in this part of the questionnaire and the related descriptive statistics can be seen in tables $2,3,4,5$, and 6 . Responses were arranged on a five-point Likert-type scale, where a value of 5 corresponded to "strongly agree" and a value of 1 corresponded to "strongly disagree". The Statistical Package for Social Sciences 17.0 (SPSS) was used to analyze the questionnaire results. First, a reliability analysis was made to determine the scale's reliability and evaluate the correlation coefficients. The estimate for Cronbach's alpha $(\alpha)$ on the scale was $\alpha=0.97$, indicating that the questions had high reliability.

ANOVA test was applied to analyze the differences among the landscape enterprises in terms of their various features. The comparisons were conducted based on their business field, operation time, customer groups, main aims, and employee status. For all evaluations, the significance levels (P) were 0.01 and 0.05 . The Spearman correlation test was used to evaluate the statistical strength of the 
Table 2 - Assessment of landscape enterprises about stages of organizing.

\begin{tabular}{|c|c|c|c|}
\hline \multirow[t]{2}{*}{ Expression code - Expression } & \multicolumn{3}{|c|}{ 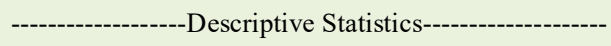 } \\
\hline & M (Mean) & s (Standard Deviation) & $\mathrm{s}^{2}$ (Variance) \\
\hline E1. The works are done toward the aims of the organization determined in detail. & 4.23 & 0.73 & 0.53 \\
\hline E2. Units have been created under the works done by the organization. & 4.00 & 0.97 & 0.94 \\
\hline E3. Sufficient human resources were allocated to each unit. & 3.71 & 1.07 & 1.15 \\
\hline E4. Each unit has adequate tools and equipment. & 4.03 & 0.92 & 0.85 \\
\hline E5. The duties of the units were determined. & 3.97 & 0.98 & 0.97 \\
\hline E6. The authority and responsibilities of the units were defined. & 4.09 & 0.91 & 0.84 \\
\hline E7. Task distribution was made within the units. & 4.31 & 0.71 & 0.51 \\
\hline E8. Chain of command and hierarchical relations were defined. & 3.94 & 1.16 & 1.35 \\
\hline E9. Formal relations between different units were determined. & 3.94 & 1.02 & 1.05 \\
\hline
\end{tabular}

relationship between the variables.

\section{RESULTS AND DISCUSSION}

\section{Assessment of landscape enterprises' organizing processes}

The questions regarding the stages of organizing were considered at a high level $(\mathrm{M}=4.02)$. In the context of these related questions, the participants indicated that the departments carried out duty assignments, that activities were determined in detail according to the enterprises' aims, and that the enterprise's management level determined authorities and responsibilities (Table 2). The other highly considered expressions concerned the adequacy of department equipment and the compatibility of the departments with the organizational activities. The staff's adequacy in departments, the clarity of hierarchical relations, relations between different departments, and the existence of duty definitions are moderately evaluated (Table 2). There were no significant differences concerning the stages of organizing in terms of business field, operation time, customer groups, aims of the enterprises, or staff and technical personnel (Table 7).

The second set of questions was analyzed according to organizing processes and related principles. The participants stated that all employees were accountable to their superiors, daily activity was managed by low-level supervisors, and senior managers managed more complicated and general activities. The duties of individual staff members were allocated according to their expertise. The enterprises evaluated at a high level the issues of departments' contribution level to the enterprise's aims, the departments' compatibility with maintaining enterprise's purposes, effectiveness of job sharing, flexibility of the organizational structure for meeting current requirements, and efficiency of the organizational structure. Delegation of decisionmaking authority, compatibility of staff with administrative activities, and staff taking orders from their supervisor(s) were all moderately evaluated aspects (Table 3). The statistical analysis revealed no significant difference among the participants regarding the independent variables related to organizing principles (Table 7).

The effects of organizing were evaluated in the context of nine aspects, all of which had high response rates of between 4.06 and 4.23 (M) (Table 4). This analysis considered the impact of organizational structure on productivity, coordination, division of labor, communication, integration of sectoral and technological developments, conflict management, effective time usage, resource utilization, and monitoring effectiveness. Based on ANOVA results, there were statistically significant differences between enterprises according to serviced customer groups $(\mathrm{P}=0.01, \mathrm{~F}=5.08)$ and the number of employees $(\mathrm{P}=0.05, \mathrm{~F}=3.16)$ (Table 7).

Organizational relations were evaluated and all but one of the questions related to this issue had high response rates, with means (M) of between 4.40 and 4.00 (Table 5). These questions with high response rates were related to friendship in the organization, the support enterprises provided for facilitating informal relationships, hierarchical relations, information sharing of employees with managers, supervision effectiveness, organizational communication and cooperation, and awareness 
Table 3 - Assessment of Landscape Enterprises about principles of organizing.

\begin{tabular}{|c|c|c|c|}
\hline \multirow[t]{2}{*}{ Expression code - Expression } & \multicolumn{3}{|c|}{ 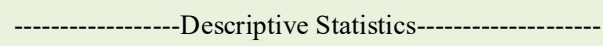 } \\
\hline & M (Mean) & s (Standard Deviation) & $s^{2}$ (Variance) \\
\hline $\begin{array}{l}\text { E10. Each unit in the organization contributes to the realization of the enterprise's } \\
\text { aims. }\end{array}$ & 4.23 & 0.64 & 0.41 \\
\hline E11. Organizational units are suitable for achieving the aims of the organization. & 4.23 & 0.59 & 0.35 \\
\hline $\begin{array}{l}\text { E12. The organization was created toward the achievement of its aims at the } \\
\text { lowest cost. }\end{array}$ & 4.00 & 0.64 & 0.41 \\
\hline $\begin{array}{l}\text { E13. The number of employees that each superior directs is compatible with th } \\
\text { work done. }\end{array}$ & 3.89 & 0,99 & 0,98 \\
\hline E14. Managers delegate related decision-making authority to employees. & 3.49 & 1.14 & 1,31 \\
\hline E15. Each employee in the organization takes orders from her/his superior. & 3.97 & 0.74 & 0.55 \\
\hline E16. Each employee is responsible to her/his superior. & 4.40 & 0.49 & 0.24 \\
\hline E17. There is an effective division of labor in the organization. & 4.17 & 0.66 & 0.44 \\
\hline $\begin{array}{l}\text { E18. The organizational levels progress uninterruptedly in terms of authority and } \\
\text { responsibility. }\end{array}$ & 4.06 & 0.72 & 0.52 \\
\hline E19. Specialization is taken into consideration in the organizing process. & 4.26 & 0.56 & 0.31 \\
\hline $\begin{array}{l}\text { E20. Routine works are carried out by the lower-level employee, while senior } \\
\text { managers make the decisions related to the enterprise. }\end{array}$ & 4.29 & 0.92 & 0.85 \\
\hline $\begin{array}{l}\text { E21. The organizational structure is changed according to the periodic } \\
\text { requirements. }\end{array}$ & 4.11 & 0.79 & 0.63 \\
\hline
\end{tabular}

about administrative aims, decisions, and current developments. The item with the lowest response rate in this group was "organizational relations being about the communication between the staff of different departments" $(\mathrm{M}=3.94)$. The ANOVA test revealed significant differences among the enterprises regarding serviced customer groups $(\mathrm{P}=0.04, \mathrm{~F}=3.52)$.

The participants also evaluated authority and responsibility-related items. The statement "senior managers made the decisions" was supported by the highest number of participants $(\mathrm{M}=4.51)$, followed by the distribution of duty, authority, and responsibility, monitoring results of authority delegation, and the aspects of process and principles of authority delegation. The factors related to participatory decision making, the delegation of authority, the equivalence of authority and responsibility, decision making by department managers, and staff's right to take initiatives in decision making and executing orders all had more moderate response rates. The organizational aspect related to the department's independent decision-making had a low response rate $(M=2.86)$ (Table 6). A significant difference was observed in customer groups, categorized under authority and delegation-related issues based on ANOVA test results (Table 7).

Relations and impacts of organizing-related factors
Results from the correlation analysis indicated significant relationships among the evaluated aspects of landscape enterprises' organizing function (Table 8). The results showed a positive correlation between the stages of organizing, related principles, impacts of organizing, authority and responsibility, and organizational relations. In other words, all the components had direct and positive links with each other. Furthermore, the highest correlation was determined between stages and principles of organizing function $(\mathrm{r}=0.82, \mathrm{P}=0.00)$. Conversely, the weakest correlation was between organizational relations and impacts of organizing function $(\mathrm{r}=0.61$, $\mathrm{P}=0.00$ ) (Table 8 ). In general, there were positive and strong correlations between the components of the research theme, and when there was an increase in one of the aspects, there was an increase in the other aspects.

In addition to determining the correlations between the independent variables, the questions were analyzed independently from each other. It was reported that nine dependent variables correlate with the enterprise's main aims, and six had correlations with customer groups. Moreover, operation types regarding the landscape sector and outside of the landscape sector had correlations with three variables. These findings indicated that the aims of the

Ciência Rural, v.52, n.7, 2022. 
Table 4 - Assessment of Landscape Enterprises about effects of organizing.

\begin{tabular}{|c|c|c|c|}
\hline \multirow[t]{2}{*}{ Expression code - Expression } & \multicolumn{3}{|c|}{ 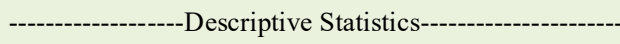 } \\
\hline & M (Mean) & s (Standard Deviation) & $\mathrm{s}^{2}$ (Variance) \\
\hline E22. The organizational structure makes the enterprise effective. & 4.17 & 0.66 & 0.44 \\
\hline $\begin{array}{l}\text { E23. The organizational structure strengthens harmony and coordination } \\
\text { between units and employees. }\end{array}$ & 4.23 & 0.42 & 0.18 \\
\hline E24. The organizational structure enables an effective division of labor. & 4.14 & 0.64 & 0.42 \\
\hline E25.The organizational structure strengthens internal communication. & 4.23 & 0.59 & 0.35 \\
\hline $\begin{array}{l}\text { E26. The organizational structure facilitates following sectoral developments } \\
\text { and technological innovations. }\end{array}$ & 4.06 & 0.83 & 0.70 \\
\hline $\begin{array}{l}\text { E27. The organizational structure supports the reduction of conflicts and the } \\
\text { development of relations between employees. }\end{array}$ & 4.11 & 0.63 & 0.39 \\
\hline $\begin{array}{l}\text { E28. The organizational structure ensures the ability to respond quickly to the } \\
\text { demands of customers. }\end{array}$ & 4.23 & 0.59 & 0.35 \\
\hline E29. The organizational structure ensures the effective use of resources. & 4.20 & 0.67 & 0.45 \\
\hline E30. The organizational structure facilitates controlling activities. & 4.11 & 0.75 & 0.57 \\
\hline
\end{tabular}

enterprise and customer groups impacted organizingrelated aspects of the businesses.

Overall, the components of the organizing stages were taken into account by the range of sampled enterprises. Moreover, the issues that need to be improved by the sectoral enterprises include the adequacy of staff in terms of number, inter-department relations, and job definitions. Multi-dimensional landscape management and the complexity of the internal and external environment require a strategic approach. Furthermore, the fundamental principle on balance between use and conservation further complicates the business of landscape architecture. These issues play an integral part in well-designed organizational structures. Human resources are also a key component of sectors responsible for managing nature-based resources. These sectors are tasked with overseeing ecological management, sustainability, balancing and satisfying society's social demands, and income generation (YURDAKUL EROL, 2016). Considering the critical nature of these issues, they should be at the centre of landscape architectural

Table 5 - Assessment of Landscape Enterprises about organizational relations.

\begin{tabular}{|c|c|c|c|}
\hline \multirow[t]{2}{*}{ Expression code - Expression } & \multicolumn{3}{|c|}{--'- } \\
\hline & M (Mean) & s (Standard Deviation) & $\mathrm{s}^{2}$ (Variance) \\
\hline $\begin{array}{l}\text { E31. Information and orders are effectively transmitted from the highest level } \\
\text { to the lowest level employee. }\end{array}$ & 4.23 & 0.59 & 0.35 \\
\hline E32.There is effective cooperation between units within the organization. & 4.20 & 0.58 & 0.34 \\
\hline $\begin{array}{l}\text { E33. Effective communication is established between the subordinates and } \\
\text { superiors within the organization. }\end{array}$ & 4.26 & 0.56 & 0.31 \\
\hline E34. There is effective communication among the employees in the same unit. & 4.23 & 0.69 & 0.47 \\
\hline E35. There is effective communication between different unit staff. & 3.94 & 0.77 & 0.60 \\
\hline $\begin{array}{l}\text { E36. Employees have sufficient knowledge about the goals and duties of the } \\
\text { institution. }\end{array}$ & 4.14 & 0.49 & 0.24 \\
\hline $\begin{array}{l}\text { E37. Employees are informed about the current situation and developments } \\
\text { regarding the institution. }\end{array}$ & 4.03 & 0.70 & 0.49 \\
\hline E.38. Employees share information with institutions and managers. & 4.29 & 0.57 & 0.32 \\
\hline E39. Personal relationships (friendship, etc.) are strong among employees. & 4.40 & 0.55 & 0.30 \\
\hline E40. The institution supports the informal organization. & 4.31 & 0.71 & 0.51 \\
\hline
\end{tabular}

Ciência Rural, v.52, n.7, 2022. 
Table 6 - Assessment of Landscape Enterprises about organizational authorities and responsibilities.

\begin{tabular}{|c|c|c|c|}
\hline \multirow[t]{2}{*}{ Expression code - Expression } & \multicolumn{3}{|c|}{ 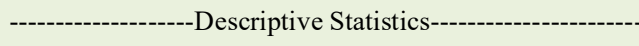 } \\
\hline & M (Mean) & s (Standard Deviation) & $s^{2}$ (Variance) \\
\hline $\begin{array}{l}\text { E41. Duties, authorities and responsibilities of employees of all levels are } \\
\text { distributed. }\end{array}$ & 4.23 & 0.77 & 0.59 \\
\hline E42. Managers are willing to transfer their authority to employees. & 3.94 & 0.93 & 0.87 \\
\hline $\begin{array}{l}\text { E43. While transferring the authority, the job description of the employees is } \\
\text { taken into account. }\end{array}$ & 4.06 & 0.72 & 0.52 \\
\hline $\begin{array}{l}\text { E44. While transferring the authority, the characteristics of the employees } \\
\text { are taken into account. }\end{array}$ & 4.09 & 0.61 & 0.37 \\
\hline $\begin{array}{l}\text { E45. The limits of the authority given to the employee during the delegation } \\
\text { are clearly defined. }\end{array}$ & 4.00 & 0.84 & 0.64 \\
\hline $\begin{array}{l}\text { E46. The standards expected when empowering employees are clearly } \\
\text { defined. }\end{array}$ & 4.09 & 0.74 & 0.55 \\
\hline E47. The authority and responsibility given to employees are equivalent. & 3.94 & 0.87 & 0.76 \\
\hline $\begin{array}{l}\text { E48. After the authority is transferred, superiors regularly control } \\
\text { employees. }\end{array}$ & 4.11 & 0.71 & 0.51 \\
\hline E49. Senior managers make decisions. & 4.51 & 0.70 & 0.49 \\
\hline E50. Unit managers make decisions. & 3.91 & 1.04 & 1.08 \\
\hline $\begin{array}{l}\text { E51. Managers seek the opinions of employees in the decision-making } \\
\text { process. }\end{array}$ & 3.97 & 1.01 & 1.02 \\
\hline E52. Decisions are allowed to be made by employees. & 3.89 & 0.96 & 0.92 \\
\hline E53. Units take decisions independently. & 2.86 & 1.11 & 1.24 \\
\hline E54. Employees are given initiative while making applications. & 3.89 & 0.83 & 0.69 \\
\hline
\end{tabular}

studies. HOLDEN \& LIVERSEDGE (2014) also emphasize the need to design well-organized teams in terms of processes, tasks, roles, responsibilities, and deliverables. They encourage learning how the design team operates, and establishing a strong communication structure between the team in landscape architectural projects.

The findings related to the organizing principles revealed that the enterprises generally followed the main principles, with the exception of authority delegation. Other aspects of the enterprises that need improvement included the span of control and unity of command. These two principles have been central and indispensable to organizational issues (MARUME \& JUBENKANDA, 2016). These issues must be considered separately for all businesses (including landscape architectural enterprises) because, as KAYMAZ \& HOŞGÖR (2018) reported, enterprises operating in the landscape architecture sector $(69 \%)$ often have multiple business fields which require effective organization.

In considering the effects of organizing, many enterprises responded that organizing had positive impacts on the managerial process. From this, it can be suggested that enterprises should focus on integrating their organizational functions using the latest sectoral developments. Furthermore, multiple case studies have highlighted the need for landscape architecture enterprises to adopt innovative approaches and enterprise-oriented strategies (CENGIZ et al., 2017; RODIEK, 2006). Lastly, a study by HARMANŞAH (2007) pointed to the importance of effective resource management and coordination of the stages of the process for the sector. There is also a need for effective communication, multi-disciplinary teamwork and coordination for landscape architectural firms (SHARKY, 2016).

The results on organizational relations revealed no challenges in the chain of command and hierarchical relations, which suggested that the inter-departmental and informal relations were managed well. However, it is essential that lateral and diagonal communication be supported and that the organizational aims, current developments, and 
Table 7 - Organization - Related Aspects of Enterprises and ANOVA Results.

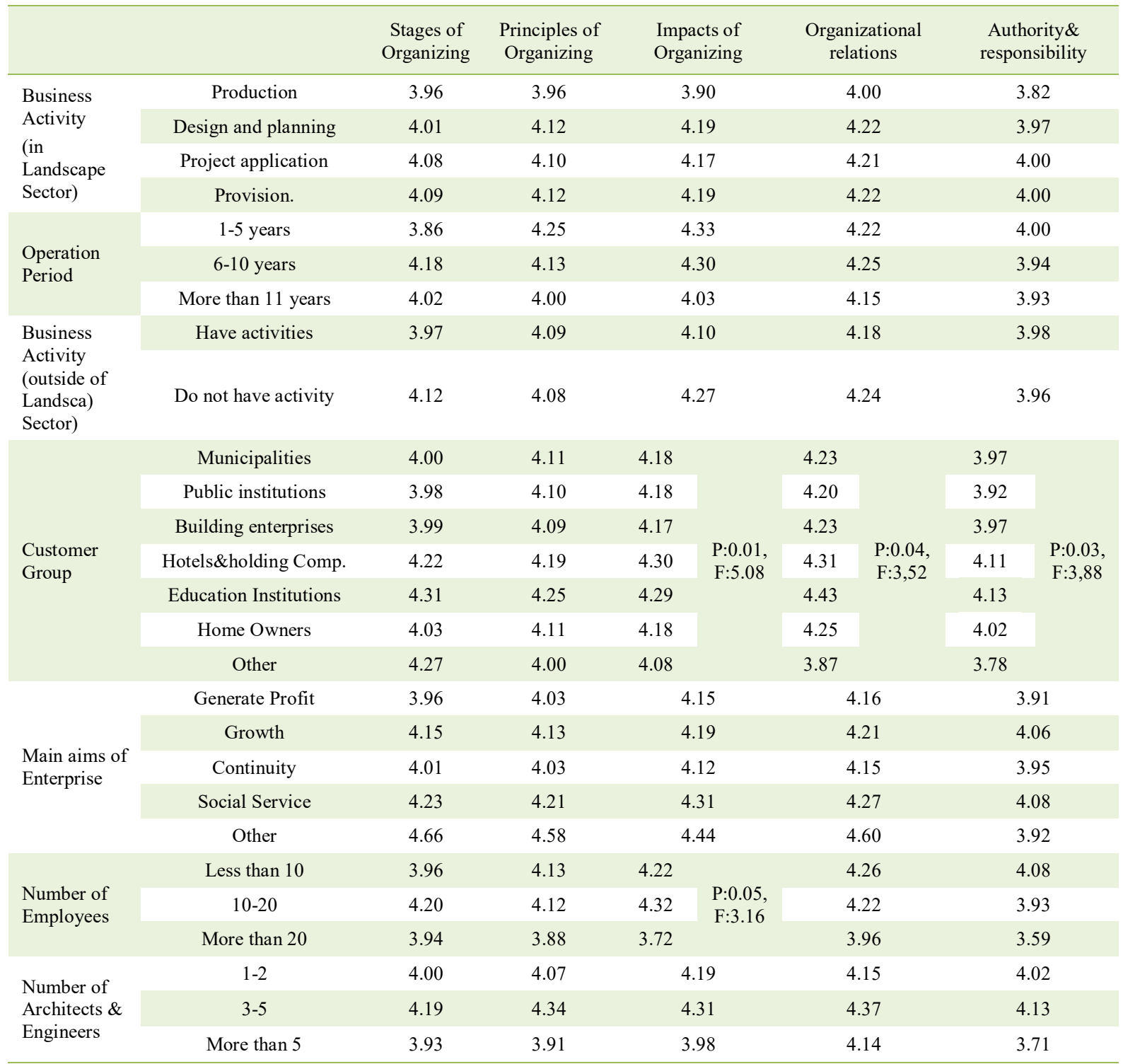

decisions be shared with staff. Interdepartmental communication is recognized as key to organizations' success due to its impact on organizational behavior (GONDAL \& SHAHBAZ, 2012). Vertical communication and information sharing also have a critical role in managerial processes, especially in face-to-face meetings, and therefore should be supported; in general, all communication techniques should be adapted to the employees' behavior (SARKA, 2014).

The findings related to authority and responsibility indicated that there are problems in delegation and participatory management processes. In particular, it was reported that the supervisors made decisions without consulting staff and that the staff did not have the liberty to make decisions and manage related activities. It was also found that departments made decisions without considering the decisions made by other departments, which resulted in coordination problems. However, careful coordination and good relations between the team members are of critical importance for the projects 
Table 8 - Correlation between aspects of oganizing.

\begin{tabular}{|c|c|c|c|c|c|}
\hline Variables & (1) & (2) & (3) & (4) & (5) \\
\hline (1) Stages of Organizing & 1 & & & & \\
\hline \multirow{2}{*}{ (2) Principles of Organizing } & $\mathrm{r}=0.82$ & $\mathrm{r}=1$ & & & \\
\hline & $\mathrm{p}=0.00$ & & & & \\
\hline \multirow{2}{*}{ (3) Impacts of Organizing } & $\mathrm{r}=0.73$ & $\mathrm{r}=0.67$ & $\mathrm{r}=1$ & & \\
\hline & $\mathrm{p}=0.00$ & $\mathrm{p}=0.00$ & & & \\
\hline \multirow{2}{*}{ (4) Organizational Relations } & $\mathrm{r}=0.64$ & $\mathrm{r}=0.62$ & $\mathrm{r}=0.61$ & $\mathrm{r}=1$ & \\
\hline & $\mathrm{p}=0.00$ & $\mathrm{p}=0.00$ & $\mathrm{p}=0.00$ & & \\
\hline \multirow{2}{*}{ (5) Authority And Responsibility } & $\mathrm{r}=0.78$ & $\mathrm{r}=0.78$ & $\mathrm{r}=0.77$ & $\mathrm{r}=0.68$ & $\mathrm{r}=1$ \\
\hline & $\mathrm{p}=0.00$ & $\mathrm{p}=0.00$ & $\mathrm{p}=0.00$ & $\mathrm{p}=0.00$ & \\
\hline Mean & 4.02 & 4.09 & 4.16 & 4.20 & 4.11 \\
\hline Std. Deviation & 0.77 & 0.44 & 0.51 & 0.46 & 0.58 \\
\hline
\end{tabular}

because of the broad interdisciplinary range of landscape architecture projects (WATERMAN, 2009). Participatory management is another issue that is regarded as a critical factor in ensuring employees' job satisfaction and securing organizational success (SOUPLY-PIERARD \& ROBEET, 2017). In fact, participation is often seen as a tool that increases the success of landscape architectural planning and design processes themselves (THOMPSON, 2005).

\section{CONCLUSION}

Organizing is the essential function of management for ensuring the implementation of plans and for monitoring performance. Thus, the organizational structure must effectively facilitate use of the enterprise's resources, the realization of its aims, and adaptation to its external environment. As the business field of landscape architecture involves ecological, architectural, economic, and social challenges, these enterprises must be well-designed with an interoperable departmental dynamic. In this study, it was determined that these enterprises' main organizational problems concerned delegation, participatory management, and inter-departmental relations. These issues are of critical importance in today's management approach and must be organized effectively to support organizational success.

The research showed that the diversity of business field in the sector, and the different characteristics of customer groups are closely related and affect the organizing process. This business and customer diversity increases the necessity of the organizing process associating it with the objectives of the firm. However, our research has determined that most organizations don't have sufficient human capital in departments and clearly defined formal relations between units.

Although, there seems to be a high compliance with organizational principles, it is clear that there are deficiencies in the delegation of authority, audit areas, and unity of command. Strengthening coordination, internal communication, and quick responses to customer demands can contribute greatly to the organizations. However, the organizations have to be strengthened in following sectoral developments, technological innovations, and conflict management.

There do not appear to be problems regarding formal relations between people within units and informal relations were strong. However, inter-departmental relations (lateral and cross relations) need to be strengthened. Also, senior managers often make decisions and subordinate units are unable to respond decisively or independently. Thus it is clear that the delegation mechanisms do not work effectively and the level of employee initiative is limited during implementation and decision-making processes. Participation in decision making and implementation is critical for landscape architecture projects, which often have a multidimensional structure. The research findings show that the independent variables with the highest impact on organizing function were customer group and the enterprise's aims.

Moreover, there is a strong relationship between stages of organizing, principles of organizing, impacts of organizing, organizational relations, and 
authority and responsibility. The assessment of the organizational aspects of landscape architecture enterprises concluded with some recommendations: (1) to adopt a holistic approach to management for enterprises with multiple business fields and diverse customer groups; (2) to strengthen delegation, participatory management, and inter-departmental relations; (3) to consider the business field, customer diversity, and aims while designing the organization; (4) to develop capacity in terms of following sectoral developments and technological innovations; (5) to improve the organization in terms of reducing and managing conflict.

There is more research that can be done on the managerial and organizational aspects of landscape enterprises. The present analysis of the case of Istanbul offers insights on the characteristics of the sector's management and organization practice. Further research that focuses on case studies should be conducted to analyse the sector and supporting the enterprises.

\section{DECLARATION OF CONFLICT OF INTEREST}

The authors declare no conflict of interest. The founding sponsors had no role in the design of the study; in the collection, analyses, or interpretation of data; in the writing of the manuscript, and in the decision to publish the results.

\section{ACKNOWLEDGMENTS}

This article was produced from the master's dissertation entitled as entitled "Peyzaj İşletmelerinde Örgütleme İșlevi ve Örgüt Yapıları Organizing function and Organizational Structures in Landscape Enterprises" conducted at Istanbul University-Cerrahpasa Institute of Graduate Studies.

\section{AUTHORS' CONTRIBUTIONS}

Conceptualization: Nur Aytül TEMIZ and Seçil YURDAKUL EROL. Data acquisition: Nur Aytül TEMIZ. Design of methodology: Seçil YURDAKUL EROL. Data analysis: Nur Aytül Temiz and Seçil YURDAKUL EROL. Seçil YURDAKUL EROL prepared the draft of the manuscript. Both of the authors critically revised the manuscript and approved of the final version.

\section{REFERENCES}

AHMADY, G.A.; et al. Organizational Structure. Procedia social and Behavioral Sciences, v. 230, p.455-462, 2016. Available from: <https://doi.org/10.1016/j.sbspro.2016.09.057>. Accessed: Dec. 06, 2020. doi: 10.1016/j.sbspro.2016.09.057.

ASLA (American Society of Landscape Architects). What is landscape architecture? Available from: <https://www.asla.org/ aboutlandscapearchitecture.aspx>. Accessed: Jun. 05, 2020.
BALIG, H.H. Organization structures-theory and design, analysis and prescription. Springer, USA, 2006, 483p.

CENGIZ, B.; et al . Peyzaj ekonomisi açısından peyzaj ve süs bitkileri fidanlık işletmelerine yönelik sektörel bir analiz. Journal of Bartın Faculty of Forestry. v.19 (n2), p.50-62, 2017. Available from: <https://dergipark.org.tr/tr/download/article-file/370450>. Accessed: Sep.10, 2020. doi: 10.24011/barofd.344677.

DAVIS, B.; OLES, T. From Architecture to Landscape. Places Journal, 2014. Avaible from: <https://placesjournal.org/article/ from-architecture-to-landscape>. Accessed: May.05,2020.

DIVE, B. The healty organization-a revolutionary approach to people \& management. Kogan Page, London, 2004, 294p.

DIEFENBACH, T.; SILLIENC, J.A.A. Formal and informal hierarchy in different types of organization. Organization Studies, v.32(n.11), p.1515-1537, 2011. Avaible from: <https://doi. org/10.1177/0170840611421254>. Accessed: Feb. 22, 2021. doi: $10.1177 / 0170840611421254$.

DRUCKER, P.F. Management: Task, Responsibilities, Practices. Classics in Organization and Management Series, NewYork: Transaction Publishers, 2007, 553p.

DYCK, B.; NEUBERT, M. J. Management: Current practices and new directions. U.S.A.: Houghton Mifflin Harcourt Publishing Company, 2009, 587p.

ENTWISTLE, T.; KNIGHTON, E. Visual communication for landscape architecture. AVA Publishing, London, 2013, 200p.

FOSTER, I. Becoming a landscape architect: a guide to careers in design. New Jersey: John Wiley and Sons, 2010, 354p.

GONDAL, U. H.; SHAHBAZ, M. Interdepartmental communication increases organizational performance keeping HRM as a Mediating Variable. Journal of Asian Business Strategy v.2(n.6), p.127-141, 2012. Avaible from: <http://www. aessweb.com/pdf-files/4-49-2(6)2012-JABS-127-141.pdf $>$. Accessed: Oct.02, 2020

GÜL, A. Peyzaj-İnsan İlişkisi ve Peyzaj Mimarlı̆̆ı. Süleyman Demirel Üniversitesi Orman Fakültesi Dergisi A(1), p.97-114, 2000. Avaible from: $<$ https://dergipark.org.tr/tr/download/articlefile/195597>. Accessed: Jun.18, 2020.

HALUSHACK, O; HALUSHCHAK, M. Some aspects of the organizing of administrative management in organizations. Socio-Economic Problems and the State. v.12(n.1), p. 230238, 2015. Avaible from: $<$ https://sepd.tntu.edu.ua/images/stories/ pdf/2015/15hoyuvo.pdf $>$. Accessed: Feb. 22, 2021.

HARMANŞAH, E. Peyzaj Mimarlığı Hizmetleri Yönetim Modellemesi. Ankara Üniversitesi, Fen Bilimleri Enstitüsü, 2007, $134 \mathrm{p}$.

HERNES, T. Understanding organization as process: Theory for a tangled world. Rourledge, New York, 2008, 173p.

HOLDEN, R.; LIVERSEDGE, J. Landscape: an introduction. Laurence King Publishing, United Kingdom, 2014, 208.

KABIRU, F.C.; et al. Influence of organizing as a management function on organizational performance among agricultural state- 
owned corporations in Kenya. International Academic Journal of Human Resource and Business Administration, v.3(n.1), p 100-125, 2018. Avaible from: <http://www.iajournals.org/articles/ iajhrba_v3_i1_100_125.pdf>. Accessed: Feb.22, 2021.

KAYMAZ, I.; HOŞGÖR, E. Özel sektörün peyzaj mimarlığı lisans eğitiminden ve mezunlarından beklentileri. Turkish Journal of Forestry v.19(n.4), p. 403-412, 2018. Avaible from: <https:// doi.org/10.18182/tjf.489812>. Accessed: May. 10, 2020. doi: $10.18182 /$ tjf. 489812 .

MARUME, S.B.M.; JUBENKANDA, R.R. The basic concepts and principles of unity of command and the span of control International Journal of Business and Management Invention, v.5(v.6), p.14-18. 2016. Avaible from: $<$ http://www.ijbmi.org/papers/ Vol(5)6/Version-2/C050602014018.pdf>. Accessed: May. 28, 2020.

MCNAMARA, D. E. From Fayol's Mechanistis to today's organic functions of management. American Journal of Business Education, v.2(n.1), p.63-78, 2009. Avaible from: <https://doi. org/10.19030/ajbe.v2i1.4023>. Accessed: Jun. 08, 2020. doi 10.19030/ajbe.v2i1.4023

MORSCHETT, D.; et al. International organizational structures as coordination mechanism. In: Morschett, D.; et al. Strategic International Management, Wiesbaden: Gabler, 2009, p.181-202.

ÖZDÖNMEZ, M.; et al. Yönetim ve Organizasyon. Istanbul Universitesi Basımevi, İstanbul, 1998, 186p.

PICOT, A.; et al. Information, Organization and Management Springer, Munich, 2008, 536p.

RODIEK, J.E. Landscape planning: its contributions to evolution of the profession of landscape architecture. Landscape and Urban Planning, v,76, p. 291-29, 2006. Avaible from: <https://doi. org/10.1016/j.landurbplan.2004.09.037>. Accessed: Jul. 03, 2020 doi: 10.1016/j.landurbplan.2004.09.037.

SARBOLAND, K. Effect of different levels of organizational structure on the productivity of human resources management. Journal of Basic and Applied Scientific Research, v.2(n.6), p. 5550-5554, 2012. Avaible from: <https://www.textroad.com/pdf/ JBASR/J.\%20Basic.\%20Appl.\%20Sci.\%20Res.,\%202(6)55505554,\%202012.pdf>. Accessed: Feb. 23, 2021
SARKA, H. Tools of Internal Communication from Knowledge Transfer Perspective. Journal of Competitiveness v.6(n.4), p. 5062, 2014. Avaible from: <https://www.cjournal.cz/files/180.pdf>. Accessed: Jun. 13, 2020. doi: 10.7441/joc.2014.04.04.

SCHRAEDER, M. et al. The function of management as mechanisms for fostering interpersonal trust. Advances in Business Research, v.5, p. 50-62, 2014. Avaible from: $<$ https:// journals.sfu.ca/abr/index.php/abr/article/view/71/91>. Accessed: Jul. 02, 2020.

SHARKY, B. Thinking about landscape architecture. Routledge, New York, 2016, 220 p.

SOUPLY-PIERARD F., ROBERT J. 2016. Participative management as a key success factor in merger and acquisition. Avaible from: <https://orbi.uliege.be/bitstream/2268/211746/1/ Participative\%20Management.pdf $>$. Accessed: Jul. 03. 2020.

SOYKA, P.A. Creating a sustainable organization-approaches for enhancing corporate valu through sustainability. Pearson Education, New Jersey, 2012, 415p.

STANFORD, N. Organization design: The collaborative approach. Great Britain: Elsevier, 2005. 306p

THOMPSON, I. H. Ecology, community and delight sources of values in landscape architecture. E \& FN Spon, New York, 2005, 243p.

TRAN, Q.; TIAN, Y. 2013. Organizational structure: influencing factors and impact on a firm. American Journal of Industrial and Business Management, v.3, p.229-236. Available from: $<$ https://www.scirp.org/pdf/AJIBM_2013042513413585.pdf $>$. Accessed: Feb.23, 2021. doi: 10.4236/ajibm.2013.32028.

WATERMAN, T. The fundamentals of landscape architecture. AVA Publishing, Switzerland , 2009, 200p.

YURDAKUL EROL, S. Comprehensive analysis of some jobrelated attitudes on expectation and satisfaction among forestry staff: case results from a Turkish regional forestry organization. International Forestry Review v.18 (n.2), p. 161-179, 2016. Available from: <https://doi.org/10.1505/146554816818966309>. Accessed: Jun. 20, 2020. doi: 10.1505/146554816818966309. 